\title{
TINJAUAN KONDISI MUARA SUNGAI REMU DALAM MENUNJANG KELANCARAN ANGKUTAN ANTAR PULAU DI WILAYAH SORONG
}

\author{
Jainab Matdoan ${ }^{1)}$, Hendrik Pristianto ${ }^{2)}$ \\ 1) Mahasiswa S-1 Program Studi Teknik Sipil Universitas Al-Amin Muhammadiyah Kota Sorong \\ 2) Dosen Fakultas Teknik Universitas Al-Amin Muhammadiyah Kota Sorong
}

\begin{abstract}
Abstrak
Alat Angkutan yang melalui sungai remu adalah kapal-kapal dari pulau-pulau terluar kota sorong yang tidak bisa di akses melalui jalan darat. Tujuan dari penelitian ini adalah untuk mengetahui volume lalu lintas kapal yang keluar masuk melalui muara sungai remu dan mengetahui faktor-faktor yang mempengaruhi lalu lintas kapal pada muara sungai remu. Penelitian ini dilaksanakan pada muara sungai remu dan dilakukan selama 21 (dua puluh satu) hari. Dengan tahapan pengumpulan data berupa data primer dan data sekuender, data yang terkumpul dianalisis dengan cara statistik sesuai dengan tujuan penelitian. Hasil dari penelitian ini bahwa kondisi muara sungai remu dalam menunjang kelancaran angkutan antar pulau di kota Sorong adalah sudah lancar hal ini karena lebar muara sungai remu sudah cukup menunjang bagi kapal-kapal yang keluar dan masuk, akan tetapi masyarakat sangat terganggu karena masih banyak kapal-kapal yang parkir pada sepanjang aliran sungai menuju hulu (dermaga). Rata-rata angkutan yang masuk pada sungai remu adalah sebanyak 56 angkutan/hari dan 51 angkutan/hari yang terdiri dari longboat, kapal layar, speed boat, sampan, katinting, taksi laut. Adapun faktor-faktor yang mempengaruhi kelancaran lalu lintas melalui sungai remu yaitu, adanya angkutan sedimen suspensi, kapal-kapal yang parkir, dan tanggul yang ada pada sungai remu.
\end{abstract}

Kata Kunci : Muara Sungai, angkutan antar pulau.

\section{P E N D A H U L U A N}

\subsection{Latar Belakang}

Muara sungai berfungsi sebagai pengeluaran/pembuangan debit sungai ke laut, terutama pada waktu banjir. Karena letaknya yang berada di ujung hilir, maka debit aliran di muara adalah lebih besar dibanding pada tampang sungai sebelah hulu.

Transportasi merupakan prasyarat utama untuk membangkitkan kegiatan sosial ekonomi pada suatu daerah. Tidak dapat dipungkiri bahwa saat ini transpotasi telah menjadi aktivitas yang menjadi tulang punggung utama untuk keberlangsungan kegiatan ekonomi, sosial, dan perkembangan teknologi pada suatu daerah.

Sungai remu adalah sungai yang membelah kota Sorong, muara sungai adalah bagian hilir sungai yang berhubungan dengan laut. Permasalahan di muara sungai dapat ditinjau di bagian mulut sungai (river mouth) dan estuari (muara sungai). Kapalkapal yang melalui sungai remu adalah kapal dari pulau-pulau terluar Kota Sorong yang tidak bisa di akses melalui jalan darat.

\subsection{Rumusan Masalah}

Berdasarkan latar belakang penelitian sebagaimana yang dikemukakan, rumusan masalah penelitian ini adalah sebagai berikut:

1. Berapa volume lalu lintas kapal yang keluar masuk melalui muara Sungai Remu?

2. Apa faktor-faktor yang mempengaruhi kelancaran lalu lintas melalui muara Sungai Remu?

\subsection{Tujuan dan Manfaat Penelitian}

Tujuan yang ingin dicapai di dalam penelitian ini adalah :

1. Untuk mengetahui volume lalu lintas kapal yang keluar masuk melalui muara Sungai Remu.

2. Untuk mengetahui faktor-faktor yang mempengaruhi lalu lintas kapal pada muara Sungai Remu. 
Penelitian tentang tinjauan kondisi muara sungai remu dalam menunjang kelancaran angkutan antar pulau di wilayah Kota Sorong, ini diharapkan dapat memberikan manfaat sebagai informasi dan ilmu pengetahuan dalam bidang teknik sungai dan transportasi.

\subsection{Batasan Penelitian}

a. Lokasi penelitian adalah muara sungai remu

b. Sampel yang di amati adalah semua jenis kapal yang akan melintasi muara sungai.

c. Kecepatan kapal di abaikan.

\section{TINJAUAN PUSTAKA}

\subsection{Muara Sungai}

Muara sungai (estuari) adalah perairan yang semi tertutup yang berhubungan bebas dengan laut, sehingga air laut dengan salinitas tinggi dapat bercampur dengan air tawar. Muara sungai berfungsi sebagai pengeluaran/ pembuangan debit sungai ke laut, terutama pada waktu banjir. Selain itu muara sungai juga harus melewatkan debit di yang ditimbulkan oleh pasang surut, yang bisa lebih besar dari debit sungai.

Selain itu muara (estuari) mempunyai nilai ekonomis yang penting, karena dapat berfungsi sebagai alur penghubung antar laut dan daerah yang cukup dalam di daratan. Dengan demikian keberadaan esturia akan mempercepat perkembangan daerah yang ada disekitarnya, karena memungkinkan dibukanya pelabuhan-pelabuhan di daerah tersebut.

\subsubsection{Morfologi Muara Sungai}

a. Muara yang didominasi gelombang laut

b. Muara yang didominasi debit sungai

c. Muara Yang Didominasi Pasang Surut

1.1.2 Sifat-Sifat Morfologi Muara Sungai

Muara sungai berada di bagian hilir dari daerah aliran sungai, yang menerima masukan debit di ujung hulunya. Dalam satu periode pasang dengan durasi sekitar 6 atau 12 jam, di estuari terkumpul massa air dalam jumlah sangat besar. Pada waktu periode surut dengan durasi yang hampir sama, volume air tersebut harus dikeluarkan ke laut, sehingga menyebabkan kecepatan aliran yang besar. Fenomena tersebut berlangsung terus menerus, sehingga morfologi estuari akan menyesuaikan diri dengan gaya-gaya hidrodinamis yang bekerja padanya.

\subsubsection{Strategi Pengelolaan Muara Sungai}

a) Mulut sungai selalu terbuka

Supaya mulut sungai selalu terbuka diperlukan dua buah jetty panjang untuk menghindari sedimentasi di dalam alur dan pembentukan sand bar.

b) Mulut sungai boleh tertutup

Pembelokan muara sungai dapat menyebabkan sungai bertambah panjang, yang secara hidraulis dapat mengurangi kemampuan untuk melewatkan debit.

\subsection{Transportasi}

Transportasi adalah perpindahan barang atau penumpang dari suatu lokasi ke lokasi lain, dimana produk yang digerakkan atau dipindahkan tersebut dibutuhkan atau diinginkan oleh lokasi lain tersebut.

\subsubsection{Peranan Transportasi}

Kemajuan transportasi juga akan membawa pada peningkatan mobilitas manusia, dimana semakin tinggi mobilitas akan semakin tinggi pula tingkat produktivitas. Dengan peningkatan produktivitas tersebut, maka akan membawa dampak pada kemajuan perekonomian.

\subsubsection{Transportasi Sebagai Suatu Sistem}

Adanya sistem transportasi ini adalah mengatur dan mengkoordinasikan pergerakan penumpang dan barang, sehingga mampu memberikan optimalisasi proses pada pergerakan tersebut.

\subsubsection{Konsep Dasar Transportasi}

Konsep transportasi didasarkan pada adanya perjalanan (trip) antara tempat asal (origin) dan tujuan (destination). Dalam suatu perjalanan, ada perjalanan yang merupakan pergerakan yang diawali dari rumah (home basedtrip) dan ada juga perjalanan yang asal maupun tujuannya adalah bukan rumah (non-home based trip) misalnya, dari tempat kerja ke pasar, dari terminal bus ke kampus, dan lain sebagainya. 


\subsubsection{Pemilihan Moda}

Pemilihan moda sangat berkaitan dengan perilaku pelaku perjalanan. Dalam berbagai situasi perjalanan, pelaku perjalanan dapat memilih satu atau lebih moda angkutan yang tersedia. Pola pemilihan moda angkutan relatif tidak akan berubah sepanjang kondisinya sama.

\subsubsection{Angkutan Sungai Menurut Undang- Undang}

Peraturan Pemerintah Nomor 82 Tahun 1999 tentang Angkutan di Perairan Pasal 1 : Angkutan sungai dan danau adalah kegiatan angkutan dengan menggunakan kapal yang dilakukan di sungai, danau, waduk, rawa, dan terusan untuk mengangkut penumpang, barang dan / atau hewan, yang diselenggarakan oleh perusahaan angkutan sungai dan danau.

\subsubsection{Jenis Angkutan Sungai}

Pelayanan angkutan sungai dan danau meliputi pelayanan angkutan penumpang dan barang. Sarana angkutan sungai pada umumnya menggunakan kapal bertipe kecil dengan kepemilikan masyarakat atau perorangan. Beberapa jenis alat angkutan sungai tradisional dan modern adalah longboat, kapal layar/kapal venes, speed boat, sampan, katinting, dan taxi laut.

\subsubsection{Keunggulan dan Kelemahan Angkutan Sungai}

a. Keunggulan Angkutan Sungai :

1) Tidak perlu membuat/membangun jalan air karena sungai sebagai prasarana sudah tersedia secara alami dan pemeliharaan prasarana yang tidak terlalu memakan banyak biaya.

2) Mampu mencapai daerah pedalaman dengan dominasi perairan.

3) Kemampuan untuk mengangkut barang tanpa mempengaruhi pembebanan pada badan sungai (daya angkut bisa besar).

4) Ramah lingkungan.

b. Kelemahan Angkutan Sungai :

1) Kecepatan umumnya lebih rendah dibandingkan dengan moda lain.

2) Kenyamanan dan standar keselamatan relatif rendah.

3) Ketersediaan sarana pendukung masih kurang.

\subsection{Faktor- Faktor Yang \\ Mempengaruhi Kelancaran Lalu \\ Lintas Pada Sungai}

\subsubsection{Pasang Surut}

Pasang Surut adalah fluktuasi muka air laut karena adanya gaya tarik benda-benda di langit, terutama matahari dan bulan terhadap massa air laut dibumi. Pengetahuan tentang pasang surut adalah penting di dalam perencanaan bangunan pantai.

\subsubsection{Pendangkalan/Sedimentasi}

\section{Sungai}

Sedimentasi adalah masuknya muatan sedimen ke dalam suatu lingkungan perairan tertentu melalui media air dan diendapkan di dalam lingkungan tersebut. Sedimentasi yang terjadi di lingkungan pantai menjadi persoalan bila terjadi di lokasi-lokasi yang terdapat aktifitas manusia yang membutuhkan kondisi perairan yang dalam seperti pelabuhan, dan alur-alur pelayaran, atau yang membutuhkan kondisi perairan yang jernih seperti tempat wisata, ekosistem terumbu karang atau padang lamun.

\subsubsection{Kapal Yang Parkir di Sungai}

Kapal-kapal yang parkir pada sungai sangatlah menganggu akitivitas kelancarannya dari daerah-daerah terpencil/pedalaman, yang menggunakan sungai sebagai sarana untuk menuju kota sebagai pusat peradaban. Umumnya angkutan-angkutan ini menuju pada daerahdaerah pedalaman yang tidak dapat di jangkau dengan jalan darat.

\subsubsection{Tanggul Sungai}

Tanggul sungai adalah salah satu bangunan yang paling utama dan paling penting dalam usaha melindungi kehidupan dan harta benda masyarakat terhadap genangan-genangan yang disebabkan oleh banjir dan badai (gelombang pasang).

\section{METODOLOGI PENELITIAN}

\subsection{Lokasi dan waktu penelitian}

Penelitian ini secara umum dilaksanakan di kota Sorong, dengan mengambil lokasi penelitian di muara sungai remu kota Sorong. Penelitian ini dilakukan selama 21 (dua puluh satu) hari. 


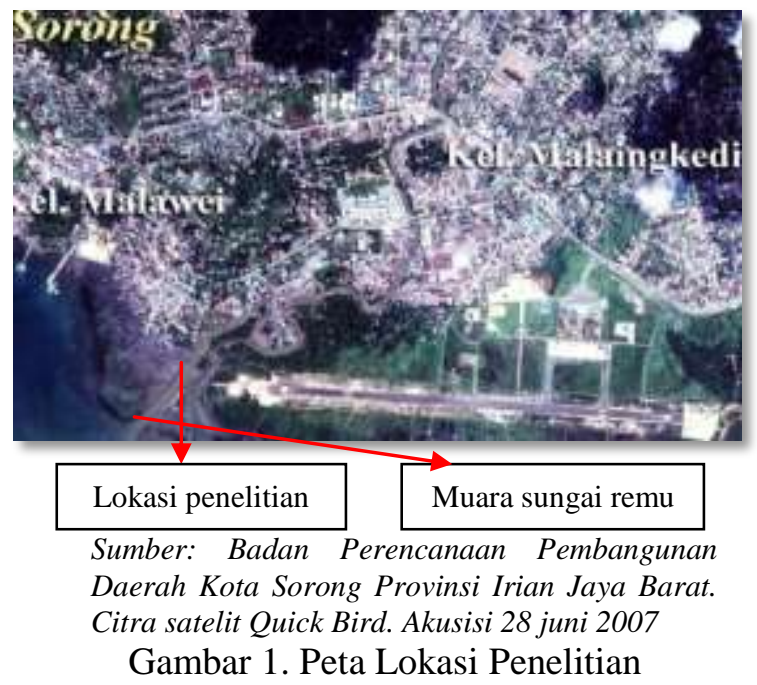

\subsection{Tahapan pengumpulan data}

\subsubsection{Data Primer}

Pengumpulan data primer merupakan pengumpulan data yang dilakukan oleh peneliti secara langsung kepada obyek penelitian. Pengumpulan data primer yang dilakukan ada dua cara, yaitu observasi dan wawancara.

\subsubsection{Observasi}

Observasi adalah teknik pengumpulan data dengan pengamatan di lapangan dan dokumentasi, sehingga diketahui kondisi sebenarnya yang tidak mungkin diperoleh dari data sekunder. Dalam penelitian ini observasi untuk mengamati kondisi muara sungai remu dalam menunjang kelancaran angkutan antar pulau di wilayah sorong.

\subsubsection{Wawancara}

Wawancara adalah cara untuk mendapatkan informasi dengan bertanya langsung kepada responden. Wawancara ditujukan pada masyarakat di tepi sungai yang berada di muara sungai remu dan pengguna angkutan antar pulau.

\subsubsection{Data Sekuender}

Pengumpulan data sekunder merupakan pengumpulan data secara tidak langsung dari sumber/obyek. Data-data diperoleh dari tulisan seperti buku-buku teori, buku laporan, peraturan-peraturan, dan dokumen baik yang berasal dari instansi terkait maupun hasil kajian literatur.

\subsection{Bahan dan Peralatan}

Bahan dan peralatan yang di gunakan dalam penelitian ini adalah literatur, alat tulis, kamera handphone, kamera digital, jam digital, papan ujian.

\subsection{Metode Pengumpulan Data}

\subsubsection{Observasi Lapangan}

Observasi adalah teknik pengumpulan data dengan pengamatan di lapangan dan dokumentasi, sehingga diketahui kondisi sebenarnya yang tidak mungkin diperoleh dari data sekunder. Dalam penelitian ini observasi untuk mengamati pergerakan angkutan sungai pada muara sungai remu.

\subsubsection{Studi Literatur}

Pada tahapan ini dikumpulkan berbagai dokumentasi, hasil-hasil penelitian dan teori-teori yang diarahkan untuk mendapat konsep penelitian yang berkaitan dengan permasalahan yang ada sebagai landasan dalam tahapan-tahapan penelitian selanjutnya.

\subsubsection{Dokumentasi}

Dokumentasi adalah upaya mencari data mengenai hal-hal atau variabel berupa catatan, buku, surat kabar, agenda, foto dan lain sebagainya. Data yang diambil untuk penelitian ini adalah berupa dokumentasi foto angkutan sungai pada muara sungai remu kota Sorong.

\subsubsection{Wawancara (Interview)}

Wawancara adalah Proses memperoleh keterangan untuk tujuan penelitian dengan cara tanya jawab sambil menatap muka antara si penanya atau pewawancara dengan si penjawab atau responden.

\subsection{TAHAPAN-TAHAPAN PENELITIAN}

Penelitian merupakan suatu siklus. Setiap tahapan akan diikuti oleh tahapan lain secara terus menerus. Tahap-tahap penelitian ini adalah :
3.5.1 Identifikasi Masalah
Identifikasi masalah adalah suatu kegiatan mencari sebanyak-banyaknya masalah yang sekiranya dapat dicari jawabannya melalui penelitian. Pencarian masalah ini bertumpu pada masalah pokok yang tercermin pada bagian latar belakang masalah. Dalam banyak tulisan dan pedoman, masalah-masalah yang akan di tulis pada bagian umumnya di sajiakan dalam bentuk kalimat tanya. Oleh karena itu, alternatif-alternatif penyebab terjadinya 
masalah akan dikumpulkan dan selanjutnya akan diteliti sesuai dengan batasan kemampuan peneliti.

Masalah yang dapat

diidentifikasikan adalah sebagai berikut :

a. Bagaimana lalu lintas keluar masuk kapal melalui muara sungai remu?

b. Apakah faktor-faktor yang mempengaruhi kelancaran lalu lintas keluar masuk kapal melalui muara sungai remu?

\subsubsection{Rumusan Masalah}

Setelah mengidentifikasikan masalah yang akan di hadapi, peneliti mulai menyusun informasi mengenai masalah yang akan dijawab atau memadukan pengetahuan menjadi suatu rumusan. Untuk itu diperlukan rumusan tujuan penelitian yang jelas, yang mencakup pernyataan tentang mengapa penelititan dilakukan, sasaran penelitian, maupun pikiran pengguna dan dampak hasil penelitian. Permasalahan yang masih samar-samar dan diragukan mulai dipertegas dalam bentuk perumusan. Dengan penelitian ini ingin diketahui faktor - faktor apa yang dapat mempengaruhi kelancaran lalu lintas melalui muara sungai remu dan mengetahui berapa volume lalu lintas kapal yang keluar masuk melalui muara sungai remu.

\subsubsection{Studi Literatur}

Studi literatur dilakukan dengan cara mencari atau mengumpulkan bahan-bahan yang berhubungan melalui :

1. Buku (text book), literatur ini didapatkan diperpustakaan.

2. Skripsi atau tesis penelitian yang sudah dilakukan, literatur ini di dapatkan dari internet dan dari perpustakaan. Topik atau tema Skripsi yang dicari adalah topik atau tema yang berhubungan dengan penelitian yang dilakukan khususnya metode pemecahan masalah yang digunakan dalam penelitian.

3. Artikel, literatur ini didapatkan dari internet.

\subsubsection{Pengambilan Data}

Data-data yang dikumpulkan diperoleh melalui wawancara kepada masyarakat pada tepi muara sungai dan pengguna angkutan antar pulau yang melalui muara sungai remu.

\subsubsection{Pengolahan Data}

Data yang dikumpulkan selanjutnya diklasifikasikan dan diorganisasikan secara sistematis serta diolah secara logis menurut rancangan penelitian yang telah ditetapkan. Pengolahan data diarahkan untuk memberi argumentasi atau penjelasan mengenai skripsi yang diajukan dalam penelitian.

\subsubsection{Analisa Data}

Analisis data bermaksud atas nama mengorganisasikan data, data yang terkumpul banyak sekali dan terdiri dari catatan lapangan dan komentar peneliti,gambar, foto, dokumen, laporan, dan lain-lain, dan pekerjaan analisis data adalah mengatur, mengurutkan, mengelompokkan dan memberikan suatu kode tertentu dan mengkategorikannya, pengelolaan data tersebut bertujuan untuk menemukan tema dan hipotesis.

Analisis data dilakukan dalam suatu proses, proses berarti pelaksanaannya sudah mulai dilakukan sejak pengumpulan data dan dilakukan secara intensif, yakni sesudah meninggalkan lapangan, pekerjaan menganalisis data memerlukan usaha pemusatan perhatian dan pengarahan tenaga fisik dan pikiran dari peneliti, dan selain menganalisis data peneliti juga perlu mendalami kepustakaan guna mengkonfirmasikan atau menjustifikasikan teori baru yang barangkali ditemukan.

Rizki Permata Sari (2008 : 18) menyatakan bahwa metode deskriptif adalah suatu metode dalam meneliti status sekelompok manusia, suatu obyek, suatu system pemikiran, ataupun suatu peristiwa atau kondisi sekarang dengan tujuan membuat deskripsi, gambaran atau lukisan secara sistematis, faktual dan akurat mengenai fakta-fakta, sifat-sifat dan hubungan antara fenomena yang diselidiki. Dengan demikian, dapat dikatakan bahwa penelitian ini berusaha untuk menggambarkan dan mengembangkan faktafakta yang ada di lapangan dengan interpretasi yang tepat (mendalam) dengan menggunakan teori-teori yang berkaitan dengan penelitian, yaitu tinjauan kondisi muara sungai remu dalam menunjang kelancaran angkutan antar pulau. Data yang terkumpul dianalisis dengan cara statistik sesuai dengan tujuan penelitian. 


\subsubsection{Kesimpulan}

Pada tahap ini dilakukan penyimpulan terhadap hasil penelitian yang dilaksanakan, berdasarkan hasil pengolahan data dan analisis pembahasan masalah. Kesimpulan ini berupa pernyataan-pernyataan yang menggambarkan keadaan masalah yang sebenarnya serta jawaban dari penyelesaian masalah.

\section{ANALISA DAN PEMBAHASAN}

\subsection{Analisa Perhitungan Volume Lalu Lintas Pada Sungai Remu}

Berdasarkan hasil penelitian pada muara sungai remu selama 21 (dua puluh satu) hari. Maka diperoleh data sebagai berikut ini :

Tabel 1. Angkutan pada sungai remu

\begin{tabular}{clcccc}
\hline \multirow{2}{*}{ No } & \multirow{2}{*}{ Alat Angkutan } & \multicolumn{2}{c}{ Jumlah Angkutan } & \multicolumn{2}{c}{ Rata-Rata } \\
\cline { 3 - 6 } & & Masuk & Keluar & Masuk & Keluar \\
\hline 1 & Long boat & 831 & 684 & 40 & 33 \\
\hline 2 & Kapal Layar & 52 & 94 & 2 & 4 \\
\hline 3 & Speed boat & 32 & 33 & 2 & 2 \\
\hline 4 & Sampan & 91 & 88 & 4 & 4 \\
\hline 5 & Katinting & 133 & 142 & 6 & 7 \\
\hline 6 & Taksi Laut & 28 & 31 & 1 & 1 \\
\hline & Jumlah & & & 56 & 51 \\
\hline
\end{tabular}

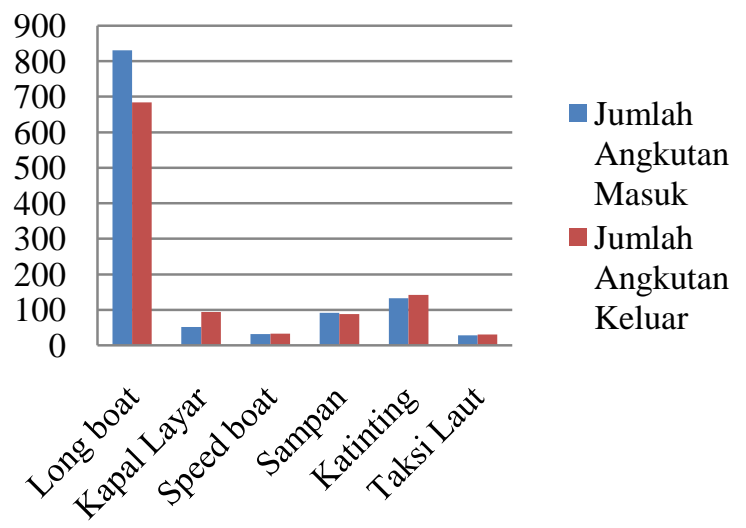

Gambar 2. Grafik Lalu Lintas Pada Sungai Remu

Dari hasil Penelitian bahwa alat angkutan yang sering di gunakan masyarakat melaui sungai remu adalah long boat, ini karena kebanyakan masyarakat yang datang dari pulau mereka menjual hasil perikanan dan perkebunannya menggunakan longboat pribadi mereka sendiri. Beberapa hari sebelum perayaan natal masyarakat yang datang dari pulau sangat banyak karena mereka harus mempersiapkan perlengkapan untuk menyambut hari raya natal.

\subsection{Persentase Hasil Interview}

\section{A. Usia}

Persentase usia pengguna angkutan melalui sungai remu sebesar $33 \%$ yang terdiri pada usia 20-29 tahun dan pada usia 30-39 tahun rata-rata mereka adalah masyarakat yang menjual hasil perkebunan dan perikanan, misalnya ; kelapa, sagu, ikan, udang dan lain-lain.

\section{B. Jenis Kelamin}

Pengguna angkutan antar pulau terdiri dari jenis kelamin laki-laki dan perempuan, pengguna angkutan antar pulau ini di dominasi oleh laki-laki karena mereka yang mengemudikan alat angkutan.

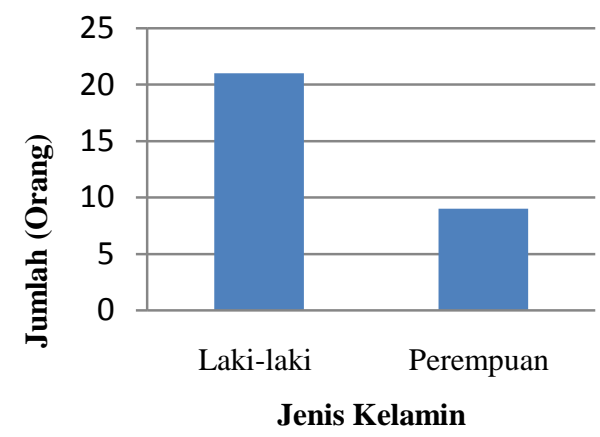

Gambar 3. Grafik Jumlah Jenis Kelamin Masyarakat Pengguna Angkutan.

\section{Jenis Angkutan Yang Digunakan}

Jenis angkutan yang sering di gunakan masyarakat melalui sungai remu adalah sebagai berikut : Long boat, Kapal layar/kapal venes, Speed boat, Sampan, Katinting, dan Taxi laut.

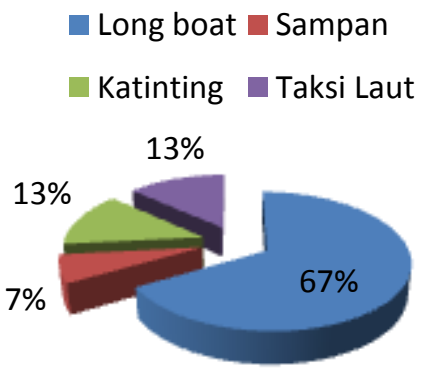

Gambar 4. Persentase Jenis Angkutan 
ISSN $1979-7450$

\section{Tujuan Perjalanan}

Umumnya tujuan masyarakat dari pedalaman datang ke Sorong sebagai pusat kota adalah mereka yang berbelanja dan berdagang. Setelah meraka menjual hasil perkebunan atau perikan mereka membeli lagi barang atau bahan jualan yang nantinya akan di jual pada daerah/kampung mereka lagi.

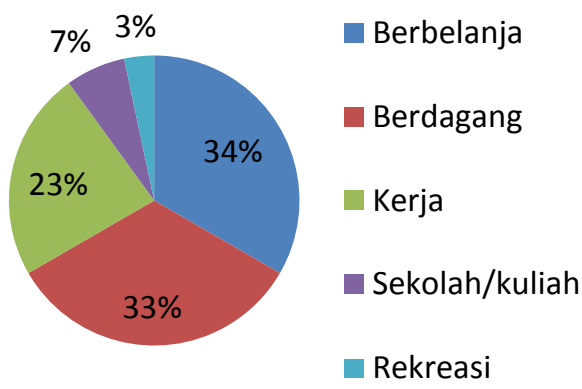

Gambar 5. Persentase Tujuan

\section{E. Intensitas Pemakaian Angkutan}

Intensitas pemakaian angkutan antar pulau melalui sungai remu adalah sebesar 43,3\% karena angkutan yang di gunakan masyarakat adalah taxi laut yang beroperasi seminggu 2 kali, yaitu pada hari senin dan rabu.

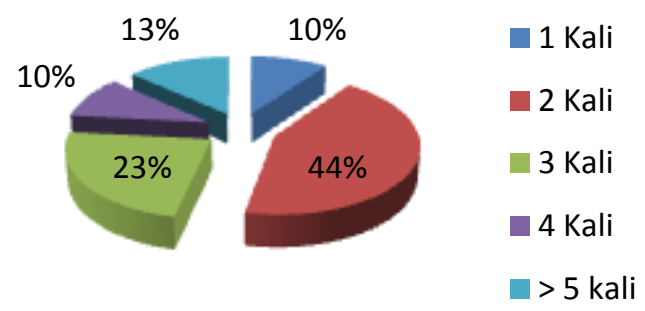

Gambar 6. Persentase Intensitas Pemakaian Angkutan

\section{F. Tingkat Pendidikan}

Dari hasil survey di lapangan bahwa tinggkat pendidikan masyarakat pengguna angkutan antar pulau melalui sungai remu yaitu ; Sekolah Dasar, Sekolah Lanjutan Tingkat Pertama, Sekolah Lanjutan Tingkat Atas dan Sarjana.

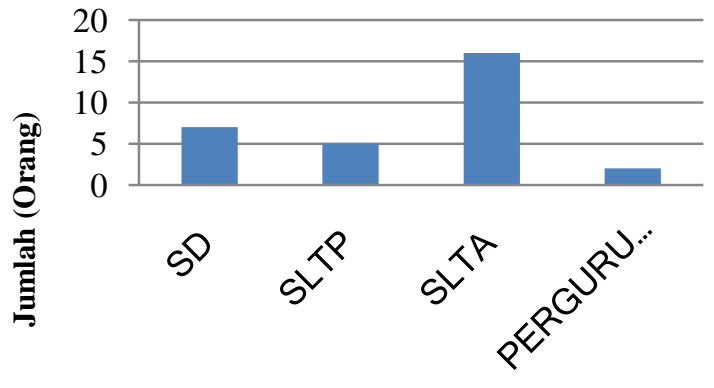

Tingkat Pendidikan

Gambar 7. Grafik Tingkat Pendidikan Pengguna Angkutan Antar Pulau

\section{3 Perubahan Morfologi Sungai Remu A. Sifat Morfologi Sungai Remu}

Pendangkalan menyebabkan masalah pokok yaitu adanya ketidak-lancaran pembuangan debit banjir ke laut sehingga luapan air di daerah hulu, dan terganggunya kapal-kapal yang memanfaatkan mulut sungai sebagai alur pelayaran. Pada muara sungai remu di manfaatkan sebagai jalur lalu lintas kapal maka muara sungai remu harus selalu terbuka. Untuk itu perlu dilakukan pengeloaan muara sungai sebagai mulut sungai selalu terbuka supaya mulut sungai selalu terbuka.

\section{B. Kegiatan Penanggulangan Muara Sungai Remu}

Pengerukan dilakukan apabila kedalam perairan pelabuhan kurang memenuhi draf kapal yang akan berlabuh. Hal ini disebabkan kondisi asli perairan maupun akibat sedimentasi yang terjadi. Pengerukan dilakukan dengan menggunakan kapal keruk (dredgers). Dredgers berfungsi untuk menggali material, menaikkan secara 168orizont, kemudian memindahkan secara 168orizontal dan membuangnya ke lokasi pembuangan. 
ISSN 1979-7450
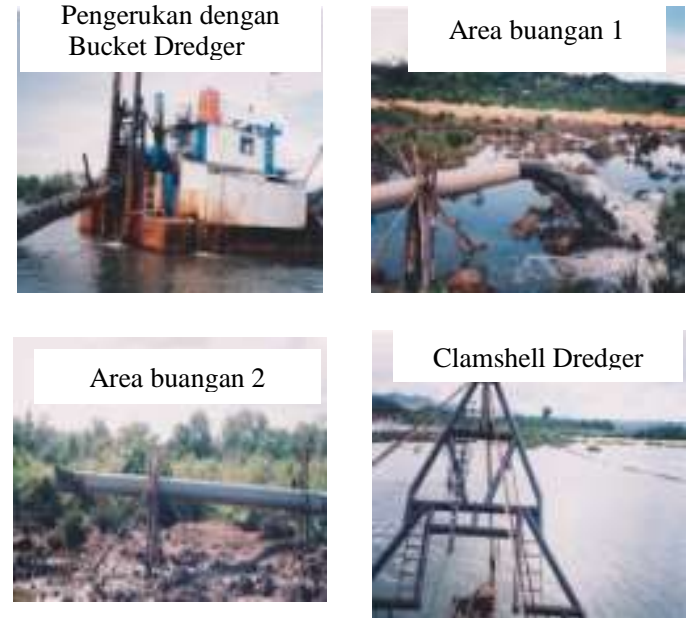

Gambar

8. Kegiatan pengerukan pada sungai remu

\section{B.Aktivitas Penduduk Pada Sungai Remu}

Aktivitas penduduk kawasan Muara Sungai Remu yang masih banyak menggunakan sungai sebagai prasarana transportasi mengindikasikan bahwa masih tingginya apresiasi masyarakat akan prasarana angkutan ini. Hal ini ditunjang dengan kondisi dimana sebagian pusat kegiatan penduduk kawasan sorong kepulauan umumnya masih berada tidak jauh dari jalur pelayaran sungai. Transportasi air yang sudah berabad-abad ada di kota sorong tetap dilanjutkan, kondisi sungai dengan kelebaran yang memadai dan juga dapat menjangkau sampai wilayah pedalaman menyebabkan sungai juga berfungsi sebagai prasarana transportasi pergerakan penduduknya.
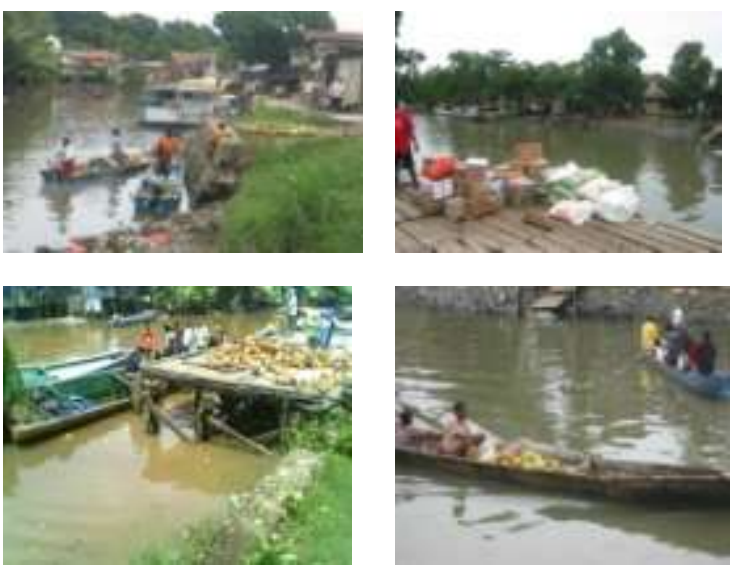

Gambar 9. Aktivitas masyarakat di sungai remu

\subsection{Faktor- Faktor Yang Mempengaruhi Kelancaran Lalu Lintas Melalui Sungai Remu}

\section{A. Sedimentasi}

Sedimentasi adalah masuknya muatan sedimen ke dalam suatu lingkungan perairan tertentu melalui media air dan diendapkan di dalam lingkungan tersebut. Proses sedimentasi berlangsung perlahan dan terus menerus selama suplai muatan sedimen yang banyak dari daratan masih terus terjadi, namun sifat yang paling penting adalah mengenai besarnya atau ukurannya. Selain adanya sedimentasi ada sungai remu banyak juga terdapat angkutan sedimen suspensi, angkutan sedimen suspensi (suspended load transport) adalah angkutan sedimen yang melayang dalam air.

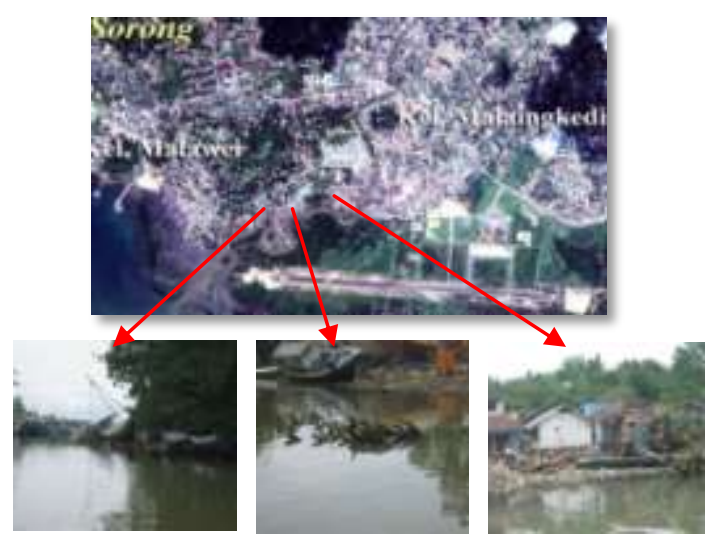

Gambar 10. Sedimentasi sampah dan bangkai kapal pada sungai remu

\section{B. Kapal Yang Parkir di Sungai}

Kondisi fisik alamiah Kota Sorong merupakan wilayah yang dialiri oleh sungaisungai yang mengalir, sungai remu adalah sungai yang selalu mengalir sepanjang tahun. Sungai ini berhulu di wilayah kali empat dan mengalir melalui wilayah kota sorong kemudian berujung pada hilir sungai remu di wilayah belakang ringo. Banyaknya kapal-kapal yang parkir pada tepi muara mengakibatkan ketidaklancaran angkutan antar pulau. Pada umumnya angkutanangkutan ini menuju pada daerah-daerah pedalaman kota sorong yang tidak dapat di jangkau dengan jalan darat. 
ISSN $1979-7450$

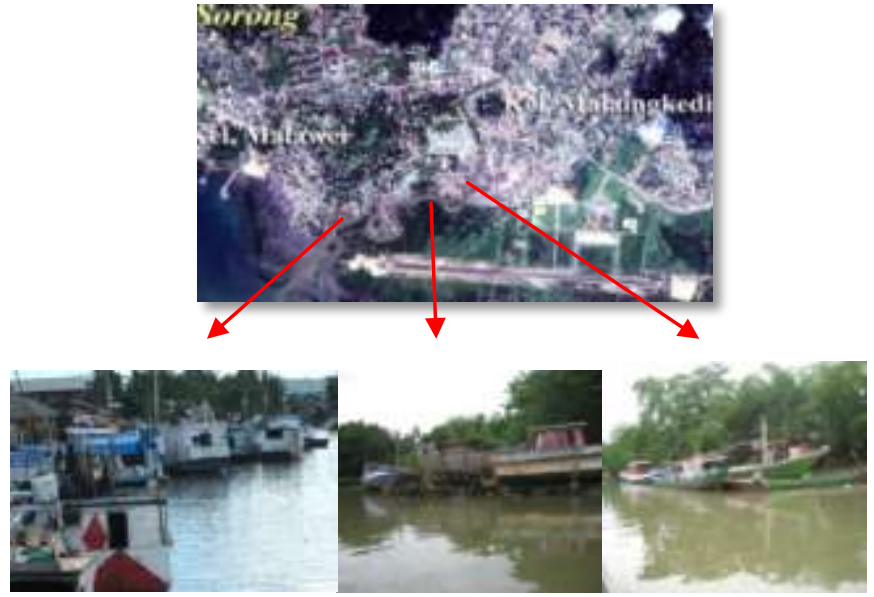

Gambar 11. Kapal-Kapal Yang Parkir Pada Sungai Remu

\section{PENUTUP}

\section{A. Kesimpulan}

Kesimpulan yang dapat kami ambil yaitu :

1. Selama peninjauan langsung di lapangan rata-rata angkutan yang masuk adalah sebanyak 56 angkutan/hari dan angkutan yang keluar sebanyak 51 angkutan/hari. Beberapa hari sebelum perayaan natal masyarakat yang datang dari pulau sangat banyak, hal ini karena mereka harus mempersiapkan perlengkapan untuk menyambut hari raya natal.

2. Persentase hasil interview pada masyarakat bahwa :

a) Usia pengguna angkutan melalui sungai remu sebesar $33 \%$ yang terdiri pada usia 20-29 tahun

b) Pengguna angkutan antar pulau ini di dominasi oleh laki-laki karena mereka yang mengemudikan alat angkutan.

c) Jenis angkutan yang sering di gunakan masyarakat melalui sungai remu adalah Long boat, kapal layar/kapal venes, speed boat, sampan, katinting, taxi laut.

d) Tujuan masyarakat dari pedalaman datang ke Sorong sebagai pusat kota adalah mereka yang berbelanja dan berdagang.

e) Intensitas pemakaian angkutan antar pulau melalui sungai remu adalah sebesar 43,3\% karena angkutan yang di gunakan masyarakat adalah taxi laut yang beroperasi seminggu 2 kali, yaitu pada hari senin dan rabu.

3. Faktor-faktor yang mempengaruhi kelancaran lalu lintas melalui sungai remu adalah kapal-kapal yang parkir pada sepanjang aliran sungai menuju bagian hulu (dermaga), tanggul sungai remu, dan sedimentasi pada dasar sungai remu serta terdapat angkutan sedimen suspensi berupa sampah yang mengapung pada sepanjang aliran sungai remu.

Dari hasil penelitian mengenai Tinjauan kondisi muara sungai remu dalam menunjang kelancaran angkutan antar pulau di kota Sorong sudah lancar hal ini karena lebar muara sungai remu sudah cukup menunjang bagi kapal-kapal yang keluar dan masuk, akan tetapi masyarakat sangat terganggu karena masih banyak kapal-kapal yang parkir pada sepanjang aliran sungai menuju hulu (dermaga) dan masih banyaknya sampah disepanjang aliran Sungai Remu.

\subsection{Saran}

Adapun saran yang kami diberikan adalah sebagai berikut :

1. Perlunya dibangunnya bangunan pelindung pada muara sungai dan perbaikan pada dermaga.

2. Kapal-kapal yang parkir sepanjang muara sungai agar di arahkan pada pelabuhan rakyat, agar tidak mengganggu aktivitas angkutan lain dari pulau terluar kota sorong yang tidak bisa diakses melalui jalan darat.

3. Adanya penyuluhan dari instansi terkait kepada masyarakat tentang pembuangan sampah pada sungai remu yang dapat mengakibatkan pendangkalan sungai dan juga banjir apabila terjadinya air pasang. Perlu sarana pembuangan sampah pada daerah sekitar muara, agar masyarakat tidak membuang sampah pada sungai remu. 


\section{DAFTAR PUSTAKA}

Anonimous, Landasan Teori. (File Pdf)

Badan Perencanaan Pembangunan Daerah Kota Sorong Provinsi Irian Jaya Barat, 2007. Citra satelit Kota Sorong. (Akusisi 28 juni 2007). \{Foto Udara\}

Bagaskoro, Wursito Adi. 2009, Kajian Pengaruh Pembangunan Jetty Terhadap Kapasitas Sungai Way Kuripan Kota Bandar Lampung. Tesis, Universitas Diponegoro Semarang. (File Pdf)

Narahawarin, Bergita, Maisun. 2010, Skripsi, Universitas Al-Amin Sorong.

Pattipeilohy, Jean, Olivia. 2007, Tugas Teknik Sungai, Makalah, Universitas Al-Amin Sorong

Sari, Rizki, Permata. 2008, Pergeseran Pergerakan Angkutan Sungai Di Sungai Martapura Kota Banjarmasin, Tesis, Universitas Diponegoro Semarang. (File Pdf)

Triatmodjo, Bambang. 2008 Teknik Pantai. Jogyakarta, Beta Offset 